\title{
'Oh you're a guy, how could you be raped by a woman, that makes no sense': towards a case for legally recognising and labelling 'forced-to-penetrate' cases as rape
}

\section{Siobhan Weare*}

\begin{abstract}
The existing legal definition of rape in England and Wales is gendered, only recognising men as offenders. The law also only recognises as victims of rape those who are penetrated by a penis, either vaginally, anally or orally. This therefore excludes the female perpetrator-male victim paradigm, and more specifically those cases where male victims are 'forced to penetrate' female perpetrators. This paper argues that consideration needs to be given to legally recognising and thus labelling forced-to-penetrate cases as rape. Applying a methodology that draws upon the lived experiences of male victims, it is argued that there are significant similarities between compelled-penetration cases and those cases legally recognised as rape, not only because they both involve non-consensual penile penetration, but because there are clear similarities in the aggressive strategies used by perpetrators and the subsequent harms experienced by victims.
\end{abstract}

\section{Introduction}

'The offence of rape, as it is defined and enforced has been the subject of an ongoing process of evaluation and reform for several decades' (Rumney, 200I, p. 890). Whilst there is extensive literature on the experiences of female victims and a growing body of work on male rape victims, 'forced-to-penetrate' cases are less well studied. Such cases, where a male victim is forced to penetrate the perpetrator's vagina, anus or mouth using his penis and without his consent, are not legally recognised as rape in England and Wales. Instead, perpetrators are prosecuted under other offences within the Sexual Offences Act 2003, namely either sexual assault ${ }^{\mathrm{T}}$ or causing a person to engage in sexual activity without consent ${ }^{2}$ (causing sexual activity). Unlike rape and assault by penetration, which are indictable offences, both sexual assault and causing sexual activity are either way offences, triable summarily or on indictment, thus reflecting the potential for offences perceived as being comparatively 'less serious' to be criminalised under these provisions.

In this paper, I argue that forced-to-penetrate cases should be considered for legal recognition and labelling as rape in England and Wales. In justifying this position, I argue that there are significant similarities in the circumstances, aggressive strategies, and physical and emotional harms experienced by victims in cases legally recognised as rape and cases of compelled penetration. I focus on these similarities through an analysis of the lived experiences of male victims in order to highlight the importance of appropriately labelling forced-to-penetrate cases as rape. When

* Lancaster University Law School. E-mail: s.weare@lancaster.ac.uk. Thanks to Professor Alisdair Gillespie and Dr Susan Leahy for their comments on earlier drafts of this paper. Thanks also to the anonymous reviewers for their helpful and constructive feedback.

I Sexual Offences Act 2003, section 3.

2 Sexual Offences Act 2003, section 4. 
considering the experiences of male forced-to-penetrate victims, I have made the conscious decision to focus on men who are compelled to penetrate women, thus allowing comparisons to be made to the experiences of female rape victims, due to the 'heterosexual' nature of both forms of sexual violence. However, in taking such an approach, I recognise that many of the arguments advanced, and experiences documented, will be relevant in relation to males forced to penetrate other males, as well as in cases of male-to-male rape.

At the outset, it is worth noting that the aim of this paper is not to consider how forced-topenetrate cases could be recognised as rape in England and Wales, namely the form that legal reform could take, but rather why such reform should occur. Such a huge question considering significant legal reform would most appropriately be considered in a separate paper where sufficient critique could be levelled against possible approaches to take. Nevertheless, it is notable that broader statutory definitions of rape exist in other jurisdictions that include compelledpenetration cases and this is an approach that could be taken in England and Wales. For example, in several states in the US, rape is broadly defined as non-consensual sexual intercourse (e.g. in Washington) ${ }^{3}$ and, in the state of Victoria in Australia, a specific offence of 'rape by compelling penetration' exists. ${ }^{4}$ Therefore, whilst it is a question that is not specifically answered within this paper, when considering what a construction of rape that includes compelled penetration could look like in English law, noting the existence of statutory provisions in, and approaches taken by, other jurisdictions is likely to be helpful. Moreover, it is clear that, in other jurisdictions, forced-topenetrate cases are recognised as rape and therefore precedent for such an approach exists.

\subsection{Methodological approach}

In developing my arguments for considering the legal recognition of compelled penetration as rape, I apply a 'lived experience' methodological and analytical framework, which allows for representation and understanding of male forced-to-penetrate victims' personal human experiences, as well as their responses to those experiences (Boylorn, 2008). The inclusion of lived experiences also helps to create a discursive space within which a more in-depth understanding of the issue of forced-to-penetrate cases can be considered. This is particularly important, as this is an area where there is currently a distinct lack of academic research and engagement. This methodological approach has also been applied as it allows forced-to-penetrate experiences to be presented for comparison with that which is legally designated as rape.

The lived experiences included in this paper are drawn from a mixture of sources, including academic literature, such as data collected and presented in journal articles/book chapters, etc., and from anecdotal evidence presented online, typically on social media platforms, in blog posts or on news websites. The inclusion of online sources is purposeful and provides a richer source of information than could be found by only using academic data due to the limited number of empirical studies conducted in this area. However, as with any phenomenological methodology, the issues of data subjectivity, reliability and validity are raised. Indeed, I recognise that the use of online posts as a source of experiences is potentially problematic for numerous reasons, including; the untestable nature of the veracity of the claims being made, the ability to anonymise online posts which creates a space within which the truth can be distorted more easily, and the potential to exclude context when posting about experiences online. These issues, however, are not only confined to the use of online sources and can also plague academic data collected in more traditional methods, such as by surveys, questionnaires and interviews.

3 See Washington, Wash. Rev. Code § 9a.44.oIo(I). 
Moreover, the anonymity associated with posting online often makes this feel like a 'safe space' (Mann and Stewart, 2000) within which people can talk about their experiences. This is particularly relevant in relation to men who are forced to penetrate women because of the gender dynamics and stereotypes involved, which may make them feel as if their masculinity has been undermined. Moreover, the level of detail given by male victims in some online posts makes this an unusual, yet potentially fruitful, source of rich data on experiences in such an under-researched area.

The diversity of sources being used where men have shared their experiences, particularly online, means that the experiences being drawn upon will be from a mixture of jurisdictions. This should not be problematic, as the legal frameworks within which the offences took place are not my primary focus; rather it is the experiences of the victims themselves with which I am concerned. Exploring the experiences of male forced-to-penetrate victims highlights the similarities shared in circumstances, aggressive strategies, and physical and emotional harms with those victims whose experiences are legally designated as rape.

\section{What is rape?}

Before considering the experiences of forced-to-penetrate victims, some, albeit brief, consideration must be given to the socio-legal discourses surrounding rape. Historically, rape was an offence committed by men against women as the property of their fathers or husbands, and was defined as 'the carnal knowledge of a woman against her will' (Hale, I97I, p. 627). The first statutory definition of rape was provided in the Sexual Offences Act 1956, which defined rape in terms of a man having non-consensual sexual intercourse with a woman. ${ }^{5}$ Buggery, criminalised in the Buggery Act 1533, remained an offence until the introduction of the Sexual Offences Act 1967, which decriminalised homosexual acts in private between men over the age of twenty-one. However, the 'heterosexual' nature of rape was maintained until the introduction of the Criminal Justice and Public Order Act 1994. This amended the Sexual Offences Act 1956, to include a broader definition of rape, which included cases of non-consensual penile-anal intercourse, thus legally recognising cases of male-to-male rape.

The terminology, centred on non-consensual vaginal or anal sexual intercourse, was maintained until the introduction of the Sexual Offences Act 2003, which replaced references to sexual intercourse with a broader definition of non-consensual, intentional penetration of the vagina, anus or mouth by a man's penis. ${ }^{6}$ In expanding the definition in this way, there was a recognition of '[s]imilarities among different forms of penile penetration of the body' (Rumney, 2007, p. 484). Therefore, central to understandings of rape is non-consensual penile penetration, historically of the vagina and more recently also of the mouth and anus, with the victim being understood as the one who is penetrated and the perpetrator as the penetrator. This is reiterated in the fact that non-consensual, non-penile penetration is dealt with under the separate offence of assault by penetration. ${ }^{7}$

Despite the contemporary recognition of male-to-male rape, rape continues to be constructed as a gendered crime, perpetrated by men against women. As Brownmiller (I975, p. 343) argues, 'to simply learn the word "rape" is to take instruction in the power relationship between males and females'. This is not an unreasonable argument to make, with the vast majority of reported rape victims being women. Indeed, the most recent detailed statistics document that, on average, 85,000 women and I2,000 men report being raped every year (Ministry of Justice et al., 20I3, p. 6). The

5 Sexual Offences Act I956, section I.

6 Sexual Offences Act 2003, section I.

7 Sexual Offences Act 2003, section 2. 
fact that the majority of victims are women, combined with the history of rape as involving nonconsensual penile-vaginal penetration and the historical illegality of buggery, means that the term 'rape' is associated with constructions of men as perpetrators and women as victims. This in turn associates rape with particular constructions of the male and female body. Women are constructed as sexually passive, vulnerable and the gatekeepers to sexual activity (Muehlenhard, I998, p. 30), whereas men are the initiators of sex, and thus are sexual actors and predators (Weiss, 2010, pp. 284, 286). Power is seen to reside in the male phallus, and the requirement of forcible penile penetration within rape arguably discursively constructs the penis as a weapon, used primarily against women. As explained by Brownmiller (I975, p. 5), 'rape became ... man's basic weapon of force against women .... His forcible entry into her body ... became the vehicle of his victorious conquest over her being ... the triumph of his manhood'.

These discourses, whilst accurately reflecting the gendered nature of rape, with women as the main victims of male perpetrators, make it difficult for men to be readily recognised as rape victims. Indeed, despite reform of the legal definition of rape to include forcible anal and oral penile penetration, thus legally including men as victims, it is well documented that men are still not readily recognised in this way. As Weiss summarises:

'Social ideals about gender may especially contribute to non-recognition of men as victims. For instance, while social constructs of femininity - as physically weak and sexually vulnerable fit overall perceptions of sexual victims, social expectations of what it is to be a man in our society - as strong, tough, self-sufficient, and impenetrable - counter images of victimisation in general and sexual victimisation in particular. With "real" men expected to avoid behaviours associated with femininity, men who are overpowered by others may be judged to have failed in their masculine duty to stick up for themselves.' (Weiss, 2010, p. 277)

The gendering of rape also means that male victims are often effeminised by their experience of being forcibly penetrated by another man (Fisher and Pina, 2013, p. 58).

The ongoing difficulty of readily recognising men as the rape victims of other men may further be reinforced by the fact that, in law, only men can be legally recognised as rapists as a result of the requirement of the perpetrator penetrating the victim with his penis. This constructs men as primarily occupying the space of the aggressor in rape, rather than that of the victim. This in turn makes it unsurprising that the female perpetrator-male victim paradigm is yet to be seriously considered. Indeed, the discursive construction of the penis as a 'weapon of force' (Brownmiller, I975, p. 5) normatively used against women makes it very difficult to conceive of alternative experiences, particularly where male victims are forced to penetrate female aggressors. Such cases challenge the idealised female victim-male perpetrator paradigm. They also challenge constructions of the male body, and thus masculinity, in more radical ways than cases of male-tomale rape, due to discourses of power in a patriarchal culture which associates power and dominance with men and the phallus. This is because, in forced-to-penetrate cases, although the man is continuing to act as the penetrator, this is occurring non-consensually and thus the penis is being used as a weapon against, rather than by, the man himself. This fundamentally distorts understandings around power and subordination in heterosexual sexual encounters, and in rape, with power seemingly residing with the woman and in the female perpetrator's vagina, rather than with the man and in the penis, in such cases.

\section{Lived experiences of male forced-to-penetrate victims}

The prevalence of forced-to-penetrate cases in England and Wales is impossible to determine. No significant data have been collected, either officially in government statistics or by academics, in 
relation to this specific type of offending. However, studies conducted in other jurisdictions, particularly the US, provide some useful statistics and highlight that a significant number of men have reported being forced to penetrate a woman. In relation to the empirical data that will subsequently be cited, it must be noted that there is variation in the definitions of 'rape' and 'sexual violence' used by researchers in their studies, which may influence results. Moreover, as is the case with the use of any empirical datasets, particularly smaller ones, any statistics cited are only representative of the sample appraised. Similarly, the well-recognised universal underreporting of sexual violence, particularly by male victims of female perpetrators (see e.g. Weiss, 2010, p. 286), must also be considered.

The most recent large-scale dataset incorporating forced-to-penetrate cases is the National Intimate Partner and Sexual Violence Survey 2010 conducted in the US; I6,507 adults were interviewed, using a random digit dial telephone survey, on their 'experiences of sexual violence, stalking, and intimate partner violence' (Breiding et al., 20I4, p. I). Defining 'being made to penetrate' for men as including forced penetration by the victims' penis or mouth into the perpetrators vagina, anus or mouth, as well as attempts (Breiding et al., 20I4, p. 8I), it was found that 'approximately I in 2I (4.8\%) of men reported that they were made to penetrate someone else during their lifetime' (Black et al., 20I I, p. 2). Of those 4.8 per cent, 79.2 per cent reported the perpetrator as being female (Black et al., 20I I, p. 24).

Smaller-scale studies have provided further evidence of the prevalence of this type of offending. For example, Krahé et al. (2003a, p. 165) conducted two studies in Berlin and Brandenburg, Germany, on 'the extent to which men become targets of women's sexual aggression'. Defining rape as penilevaginal intercourse through the use or threat of force, they found that, of the 247 younger men (with an average age of I 8.3 years) who completed the anonymous questionnaire, 2.8 per cent of them had been forced to vaginally penetrate a woman. Of the 152 older participants (with an average age of 22.3 years), 5.2 per cent of the men reported experiencing compelled penetration (Krahé et al., 2003a, p. I72).

Such limited studies and the different definitions and terminology used make it difficult to accurately assess the prevalence rate of forced-to-penetrate cases, although, based on existing research, a rate of 3-5 per cent seems likely. Whilst not the point of this paper, it is clear that more research needs to be conducted, particularly larger-scale studies, in England and Wales in this area to provide a more accurate picture.

Despite some evidence of the existence and prevalence of forced-to-penetrate cases, for many within society, there is an ongoing assumption that men simply physically cannot be forced to penetrate women. This reflects the belief that men can only 'obtain and sustain erections when sexually aroused, and therefore not in stressful or violent circumstances' (Rumney and MorganTaylor, I997, p. 333). The sentiment in such cases is typically that 'for obvious biological reasons, a woman cannot be guilty of raping a man ... clearly a woman cannot bring about sexual intercourse with a male against his will' (Rumney and Morgan-Taylor, 1997, p. 333). Thus, the experience of these men cannot truly be non-consensual, as it is only the maintenance of their erection that allows the sexual intercourse to occur. Research, however, has consistently highlighted that male victims can respond sexually when experiencing sexual violence. For example, Sarrel and Masters (I982, p. II8) found that 'men or boys have responded sexually to female assault or abuse even though the males' emotional state during the molestations has been overwhelmingly negative - embarrassment, humiliation, anxiety, fear, anger, or even terror'.

Not only can men sustain erections without being sexually aroused, but, in the same way as female rape victims can experience 'vaginal lubrication and orgasmic responses' (Smith et al., I988, p. I03) during their rape, male victims have also reported ejaculating during their forcedto-penetrate experiences (Fisher and Pina, 2013, p. 57). In the experiences analysed, one man 
who was forced to penetrate his ex-girlfriend explained how he was tied to the bed for 'a "teasing" blow-job' before his girlfriend forced him to penetrate her despite his repeated protestations. 'She got on top of me and rode me until I orgasmed against my will. I felt powerless and ashamed' (Jensen, 20I4). Thus, it is evident that 'an erection can be induced by fear and is not necessarily indicative of pleasure or consent. Such heightened emotions can create unwanted arousal in men and if stimulated, in some cases, ejaculation can occur' (Fisher and Pina, 2013, p. 57) despite a lack of consent.

\subsection{Aggressive strategies}

Even when it is recognised that a man can physically penetrate a woman without his consent, questions remain about how such forced penetration occurs. This is particularly the case because discourses around masculinity construct men as being able to protect themselves and others. However, research has highlighted that 'the activities, circumstances and context of the nonconsensual experiences appear to be similar for men and women' (Byers and O'Sullivan, I998, p. I59-I60). Indeed, although it is generally believed that men are socialised to fight back in response to an attack, research has consistently highlighted that men can 'react to extreme personal threat with frozen helplessness' (Mezey and King, I989, p. 208) in the same way as female rape victims can. Moreover, O'Sullivan, Byers and Finkelman's (I998) research has demonstrated that the aggressive strategies used in men's non-consensual experiences of sexual intercourse with women are similar to those experienced by female rape victims, including the use of coercion through verbal pressure, threats or physical force, and the use of alcohol or drugs.

It must be noted here that, whilst the types of aggressive strategies and circumstances within which non-consensual sexual intercourse takes place are similar for both male and female victims, the prevalence of the specific aggressive strategies may differ somewhat depending on the sex of the victim. Whilst female victims have most frequently reported the use of physical force or threats of harm by men as an aggressive strategy in their rape experiences (Struckman-Johnson, I988), male victims have consistently highlighted that the most frequent aggressive strategy utilised by female perpetrators in forced-to-penetrate cases is verbal pressure/persuasion/coercion. ${ }^{8}$ This most likely reflects the fact that men are typically physically stronger than women, and are therefore more likely to override a woman's consent through the use of physical force, or the threat of harm, when compared to a situation involving a female perpetrator and a male victim. That is not to say, however, that male forced-to-penetrate victims have not reported the use of this particular aggressive strategy, but rather that it has occurred less frequently than in cases involving female rape victims.

\subsubsection{Verbal pressure/persuasion/coercion}

Coercion is well recognised as an aggressive strategy within existing sexual-violence literature, particularly in the context of female victims of rape. Coercion, as discussed here, refers to nonphysical sexual pressure, namely 'persuading another individual to engage in sexual acts that he or she would not engage in otherwise through the use of deceptive or threatening psychological manipulations' (Vanderlaan and Vasey, 2009, p. 992). This could include

'being worn down by someone who repeatedly asked for sex or showed they were unhappy; feeling pressured by being lied to, being told promises that were untrue, having someone

8 Struckman-Johnson and Struckman-Johnson (I 994, p. Ioo) found that 78 per cent of men reported persuasion as a sexually aggressive tactic used by women, and Muehlenhard and Cook (I988) reported that 26.8 per cent of males had been forced into sexual contact through verbal aggression. 
threaten to end a relationship or spread rumours; and sexual pressure due to someone using their influence or authority.' (Black et al., 20II, p. I7)

Within the existing literature, coercion or verbal pressure is consistently highlighted as being the most common aggressive strategy used by women who force men to penetrate them. ${ }^{9}$

Analysing the experiences of male forced-to-penetrate victims highlights how coercion takes multiple forms. At its most extreme, the coercion for these men included threats by the female perpetrator to kill herself:

'I was I7 and dating a much older woman... I went to her apartment to break up with her and she said that if I did she would kill herself. I was naive and fell for it and blamed myself for her deluded way of thinking and fell into her manipulations. She said she would kill herself if we didn't fuck right then, to prove I still loved her and wanted her. I was young and thought that if I didn't do this I'd essentially have someone's blood on my hands. I couldn't get it up naturally, but after a while she got me erect and then she climbed on top of me.' (Jensen, 20I4)

Blackmail was also reported by several male victims, with one man recalling how

'he was being interviewed by a reporter. She promised him she would write his biography and invited him to her apartment to continue the interview. She then told him she would not write about him unless he had sex with her.' (Struckman-Johnson and Struckman-Johnson, I998, p. I35)

Another man disclosed: 'A teacher in high school found out I slept with a different teacher. She threatened to expose the situation if I didn't sleep with her' (Struckman-Johnson and StruckmanJohnson, I998, p. I35).

More general forms of verbal pressure, typically from girlfriends, were also documented on multiple occasions within the experiences analysed. This verbal pressure was often combined with the use of another aggressive strategy, such as intoxication of the victim or the use of physical violence by the female perpetrator:

'I visited my girlfriend after drinking w/guy friends. She was horny and I wasn't. We had sex once, but I was hit and yelled at when I wanted to leave w/out doing it again. I made her happy, waited for her to fall asleep/pass out, and left.' (Struckman-Johnson and Struckman-Johnson, I998, p. I35)

'She got me drunk and persuaded me. I had told her previously that I didn't want to have sex until I was married. She apologised the next day.' (Struckman-Johnson and Struckman-Johnson, I998, p. I35)

Men also reported a fear of undermining their masculinity as a factor in their experiences of coercion. More specifically, they were concerned with being negatively labelled and viewed as somehow less masculine if they rejected sex with a woman, despite not wanting to engage in intercourse. In such instances, it seems as if their forced-to-penetrate experiences were influenced more broadly by a form of societal coercion, requiring them to adhere to gender and sexuality stereotypes which enhance men's worth with sexual experience. This traditional gendered script pressures men into engaging

9 Struckman-Johnson (I 988) found that 52 per cent of men reported psychological pressure, and Sorenson and Siegel (I992) found that men were more likely to be verbally pressured for sexual contact than women. 
in sexual intercourse with women, particularly women who actively and aggressively seek sex. This was reflected in some of the experiences analysed:

'It was in high school and the girl I was with had just broken up with her steady boyfriend. We met at a party and she came on to me. She sat down to talk and I asked her what she liked to do for fun and she said "fuck." I couldn't believe she would say that then she took it to that extreme. I felt that if I didn't she would tell everyone I was a loser.' (Struckman-Johnson and StruckmanJohnson, I998, p. I35)

Although not explicitly mentioned in the experiences analysed, it is possible that such societal pressure on men to adhere to hegemonic masculine heterosexual ideals could be seized upon by female perpetrators as part of a wider coercive strategy, involving threats to 'out' them as less masculine if they refuse to engage in intercourse.

\subsubsection{Intoxication as a result of alcohol or drugs}

Alcohol and/or drugs played a significant role in many men's forced-to-penetrate experiences. This is perhaps unsurprising, as intoxication of the victim is well documented in many rape cases, as well as more broadly in cases involving other forms of sexual violence (Krahé et al., 2003a, p. I66). The limited research conducted into compelled penetration highlights the frequency with which intoxication of the victim as a result of alcohol or drugs is used as part of aggressive strategies by female perpetrators. In O'Sullivan et al.'s (I998) study, they found that 3.8 per cent of their male participants reported unwanted sexual intercourse with women using alcohol or drugs. Similar findings were documented by Krahé et al. (2003b, p. 226), who found that 5.6 per cent of women used 'exploitation of a man's incapacitated state' to force him into 'oral sex, sexual touching, and sexual intercourse'. Interestingly Weiss's analysis of sexual-victimisation narratives from the National Crime Victimisation Survey in the US found that 'men were more than three times as likely as women to reveal in their narratives that they were drinking or using drugs prior to an incident' (Weiss, 2010, p. 284). This may be explained by the damaging rape myths around intoxicated female rape victims, ${ }^{\text {,o }}$ which deter women from admitting to alcohol or drug use, or by the fact that 'more men than women use alcohol and drugs in general' (Weiss, 2010, p. 284). As Weiss posits, it may also indicate that

'men are more likely to admit to being sexually victimised when they are intoxicated since alcohol impairs a victim's ability to resist attacks and therefore provides a plausible explanation for how it was possible for men to have been victimised in the first place (especially if the person overpowering them was a woman much smaller in physical stature and strength).' (Weiss, 20I0, p. 284)

Intoxication played a significant role in many of the experiences analysed, with multiple men reporting intoxication as a result of alcohol and/or drugs in their forced-to-penetrate experiences. Many men reported being so heavily intoxicated that they were unable to consent to sexual intercourse or to resist the actions of the female aggressor. In many cases, the men themselves became drunk or were drinking with others, such as at a bar or a party, before the incident occurred. In such cases, the female perpetrator appeared to 'take advantage' of their intoxication to ensure a lack of resistance. One student reported how he was a virgin with a long-distance girlfriend when he was 'raped' by a female friend after passing out drunk after a party:

Io For example, 'someone who has willingly drunk lots of alcohol or taken drugs shouldn't then complain about being raped' (Rape Crisis, no date). 
'Like most college freshmen, I drank too much. And one night, I drank too much and was pitched out of a frat house in the dead of winter. I don't remember much, but I do remember being initially grateful for all the hands that helped push me home and into my dorm room that night. And then my eyeballs flipped themselves into the depths of my eye sockets. I woke up in my lofted bed, and there were about a half dozen people in my room hanging out. My clothing was on the floor, and I felt an invisible miasma of shame engulfing me .... My eyes retreated into orbit again .... When I regained my bearings that night, my friends were gone and gravity was a mystery to me. She was in my bed, and I couldn't tell if my back was facing the ceiling or the mattress, nor could I identify whose sweat belonged to whom. All I could feel was pressure, and after coming to my senses I put together what was happening. I felt impotent to stop it ... I asked her what had happened, and she confirmed all the details, which included consent and desire that seemed impossible to fish out of the folds of my brain.' (xojane.com, 2013)

Another victim explained the role of intoxication in his experience of being forced to orally penetrate a female perpetrator:

'We were at her friend's house and were drinking cherry vodka. I was drunk very fast. She took me to the bathroom and I ended up on the bathroom floor. She took off my pants and engaged in oral intercourse on me. That's all I remember.' (Struckman-Johnson and Struckman-Johnson, I998, p. I33)

The experiences of other men document women actively participating in their intoxication, suggesting that the perpetrators intentionally got them drunk before having sexual intercourse with them. One male student reported how, when he was studying abroad in Shanghai, other exchange students started pouring him shots:

'These women were like, "Drink, drink, drink, drink!" he said, and because it was the first place where he was legally old enough to drink, he got much too drunk too quickly. One woman had told him she wanted to thank him for helping her move in. As he drifted in and out of blackouts, he realised he was having sex with her.' (Anderson et al., no date)

Another student reported:

'This girl who I was at a party talking to offered me drink after drink. Once alone with her and "making out" she pulled down my pants and hers and put my erection in her vagina. She had sex with me for about 5 minutes when a friend saved me and come into the room and helped me get away.' (Struckman-Johnson and Struckman-Johnson, I998, p. I33)

Men have also reported being under the influence of drugs, normally voluntarily consumed, before the compelled penetration took place. For some men, this resulted in them being unable to consent to the sexual intercourse that occurred. One nineteen-year-old student disclosed how, one day after he had got stoned smoking marijuana and fallen asleep in a woman's room, he woke up to find himself being sexually violated: 'I woke up and she was doing sexual things to me ... I was in complete disbelief. There was zero consent' (Anderson et al., no date). Other men reported how, whilst under the influence of drugs, they were unable to resist the female perpetrator or to stop what was happening to them: 
'When I was fourteen, one of the first times I had ever gotten high, I was with my brother and a few friends his age, so everyone was four or five years older than me. One girl showed up after we had smoked, I presume she was sober. Anyway, when I got up to go into the bathroom in the basement, she followed me. Made me get down on the floor and got on top of me. I was incredibly out of it, couldn't figure out why this was happening or how to stop it, despite the fact that I knew it felt terrible.' (Jensen, 20I4)

'I took a few hits of acid, smoked a lot of weed and had my fair share of drinks as well. I ended up just laying sprawled out on the floor in the downstairs rec room while everyone else was upstairs. This guy's stepsister evidently thought it was a good time to do what she wanted. She was a big girl and not saying this to be mean but I wouldn't be surprised if she was at least twice my weight. I was so high I couldn't muster the ability to get her off and away from me. I just kept telling her no and shaking my head back and forth. Being on acid made the entire event pretty horrifying. Felt like I was being sucked into her and there was nothing I could do to save myself.' (Jensen, 20I4)

For all of these men recounting their experiences, the lack of consent or, perhaps more accurately, the inability to give consent as a result of intoxication from drugs or alcohol was well recognised.

\subsubsection{Physical violence or restraint}

The use of physical violence or restraint has consistently been documented as the least common aggressive strategy in cases of female-perpetrated sexual violence. Research has put the prevalence of this aggressive strategy as occurring in somewhere between 2 and Io per cent of cases. ${ }^{\text {II }}$ This may arguably reflect the fact that many women will struggle to overpower a man who does not consent to the sexual activity occurring. It may also be reflective of men being unwilling to admit the use of such violence or restraint within their forced-to-penetrate experiences for fear of it further undermining their masculinity. In the experiences analysed, two men described being physically restrained, both either by current or former girlfriends:

'I was raped by my ex-girlfriend. We were both about I9-20. She tied me to the bed for a "teasing" blowjob. Ok cool! But then she got on top of me even though I strongly, emphatically and repeatedly said "NO! STOP! NO MEANS NO!" ... But she didn’t care and she did a good job with the restraints. She got on top of me and rode me until I orgasmed against my will.' (Jensen, 20I4)

'She got me drunk and tied me up and then had sex with me 6 times in I night. She was an exgirlfriend and was getting back at me for dumping her. She was psycho.' (Struckman-Johnson and Struckman-Johnson, I998, p. I34)

The use of weapons was also documented in a minority of cases. One man described how he was threatened with a gun as a child before being forced to orally penetrate his female babysitter:

'I was 7 and my babysitter was I3. She was watching my friend and me at his family's apartment. She got his family's gun and made both of us perform sex acts on her and she performed oral sex on us. She said that if I didn't do it, she'd shoot me.' (Jensen, 2014)

I I For example, O'Sullivan, Byers and Finkelman (I998) found that I.5 per cent of male college students in their sample had engaged in unwanted sexual intercourse due to a threat or physical force, Muehlenhard and Cook (I988) found that 6.5 per cent of their male respondents were subject to physical violence in their forcedsexual-intercourse experience and Struckman-Johnson (I988) found that Io per cent of males experienced physical force as a type of sexual coercion. 
Another man was threatened with a knife whilst being sexually violated multiple times by multiple women over a twenty-four-hour period:

'One night he had been drinking and left a bar with a woman companion he had not known previously. They went to a motel where he was given another drink and shortly thereafter fell asleep. He awoke to find himself naked, tied hand and foot to a bedstead, gagged and blindfolded .... Several women were present .... When the women realised that he was awake, he was told that he had to "have sex with all of them." When he couldn't function well, he was threatened with castration and felt a knife held to his scrotum.' (Sarrel and Masters, I982, pp. I20-I2I)

The use of weapons in compelled-penetration cases is rare. However, when used, weapons may be a 'power equaliser', the only means for a female perpetrator to overpower a male victim who is stronger than her, thus ensuring his compliance and overriding his consent.

Regardless of the specific aggressive strategies used, what is so profound about all of the aggressive strategies and experiences detailed above is how similar they are to experiences of women that are legally designated and labelled as rape. Indeed, if the sexes of the perpetrators and victims were reversed in the experiences documented above, the act would most likely be criminalised as rape. The only clear difference in such cases is being compelled to penetrate for male victims and being forcibly penetrated for female victims.

\subsection{Harms}

Whilst the aggressive strategies and experiences of forced-to-penetrate victims may be similar to those of rape victims, as well as the physical involvement of penile penetration, the understanding of rape as being about the victim's body being non-consensually penetrated by a penis suggests that there must be some significant differences in the harms experienced in such cases. This has been noted by Cowan, who explains that

'failure to recognise as rape those cases in which a woman forces a man to penetrate her vaginally, orally or anally suggests that there is something specific about being non-consensually penetrated that is more fundamentally damaging, traumatic or violating than being compelled to penetrate'. (Cowan, 20I0, p. I58)

In short, the suggestion is that, whilst aggressive strategies and experiences may be similar in rape and compelled-penetration cases, victims of rape who are forcibly penetrated experience more harm than male victims who are forced to penetrate. This was the position taken by the Home Office when consulting on reforming the law on sexual offences in 2000. Whilst acknowledging that it is physically possible for a man to be forced to penetrate a woman, they made it clear that they could not be convinced that such an experience was the equivalent of rape (Home Office, 2000, p. I5). Rather, they argued that forced-to-penetrate cases were simply 'a serious assault on the man's sexual autonomy' (Home Office, 2000, p. 3I). Thus, it is to a consideration of the harms in compelled-penetration cases that I now turn, in particular considering similarities and differences in the physical, emotional and psychological harms in forced-to-penetrate cases and those cases legally labelled as rape.

\subsubsection{Physical harms}

Perhaps the most obvious physical harms associated with rape are genital injuries received as a result of being forcibly penetrated, such as cuts and bruises, lacerations and bleeding. Whilst this is true in some cases, research has repeatedly highlighted that genital injuries are not an inevitable finding, 
even in those cases involving multiple perpetrators (Morgan et al., 20I2) or where the victim is a virgin (White and McLean, 2006). In particular, studies into the prevalence of genital injuries for female victims of rape have found that many do not experience any injuries at all. Bowyer and Dalton (I997) found that, of the eighty-three case notes they reviewed of women who reported being raped, only twenty-two of them had genital injuries. More recently, research conducted in Denmark found that women experienced vaginal injuries at similar levels in cases of both nonconsensual and consensual sexual intercourse (Hoffmann, 20I2). Similarly, whilst some male rape victims may report suffering genital injuries, it is also the case that this is not true of all male victims (Tewksbury, 2007, p. 27). Thus, it is important not to essentialise associations of genital injury with rape.

In forced-to-penetrate cases, similar evidence of genital harm for male victims has not been widely reported or recorded. This may be because of the lack of research conducted in relation to such cases, or because the prevalence of genital injuries is indeed lower. In the experiences analysed for this paper, mention of penile injuries was only made in two of the cases. One male victim disclosed that his penis was left bleeding and 'terribly sore' (Jensen, 20I4), whilst another subsequently urinated 'copious amounts of blood' (Rumney and Morgan-Taylor, I997, p. 34I). Despite more recorded prevalence of genital injury in cases of rape involving forcible penetration of the victim when compared to those of compelled penetration by the victim, the inconsistency of genital harms in rape cases means that this cannot be used to fundamentally distinguish the experiences of rape victims from those who are forced to penetrate their perpetrator. Whilst, of course, such injuries may be evidentially helpful in supporting the victims' story and prosecution of the rapist, an experience can still be labelled, and indeed prosecuted, as rape without the existence of genital injuries.

The possibility of pregnancy has long been recognised as a particular physical harm potentially arising from non-consensual penile-vaginal penetration for female rape victims. Indeed, in I984, the Criminal Law Revision Committee 'sought to distinguish penile-vaginal intercourse from other forms of penetration on the ground that penile-vaginal rape risks pregnancy' (Rumney, 2007, p. 483). However, such a view faced fierce criticism, with academics such as Temkin (2002, p. 6I) arguing that all women, including infertile, menopausal and sterilised women, were protected by the law of rape, and therefore the risk of pregnancy could not be viewed in such a narrow way. The inclusion of oral and anal penetration within the existing legal definition of rape, and more readily available protections from pregnancy such as contraception, the 'morning after pill' and abortion, reflect the fact that the risk of pregnancy is no longer central to understandings of rape. Thus, this arguably cannot be used to justify the exclusion of forced-to-penetrate cases from being legally recognised and labelled as rape.

Although there is no risk of pregnancy as a physical harm occurring to the victim in forced-topenetrate cases as in cases of female rape, there is however a risk of the female perpetrator becoming pregnant as a result of compelling the male victim to have vaginal intercourse with her. One forced-to-penetrate victim explained the emotional and psychological distress experienced as a result of the possibility of his assailant being pregnant, explaining how he was, as he put it, 'raped' by his ex-girlfriend when they met to discuss their break-up. A few weeks after the assault, 'she texted him to say that she thought she might be pregnant' (Anderson et al., no date). He panicked and was concerned that he would lose his family, especially as 'his parents had made it clear that he would be on his own if he ever fathered a child out of wedlock' (Anderson et al., no date). This is similar, although perhaps not as frequently and intensely experienced, to the situation for female victims of rape. However, it should be noted that, for female victims, there are multiple contraceptive options to prevent the pregnancy, including abortion, whereas, for male forced-to-penetrate victims, it may be that they have little say in, or knowledge of, whether they bear a child as a result of their experience. Whilst the fear of pregnancy may occur differentially 
and less frequently for male forced-to-penetrate victims, as they are not the ones who actually experience the pregnancy, the lack of control they have in relation to this particular harm may reinforce the trauma for the male victims involved.

Finally, the possibility of acquiring sexually transmitted infections (STIs) as a result of rape has been well documented for both male and female victims (see e.g. Amar and Wolbert Burgess, 2009; Ledray, 2005). STI transmission can include infections such as gonorrhoea, chlamydia, syphilis and HIV (Amar and Wolbert Burgess, 2009, p. 28). This physical harm is equally as applicable in cases of compelled penetration as in cases of rape, due to the involvement of sexual penetration through which STIs are transmitted. Whilst most STIs can be treated relatively easily and effectively, some that are left untreated can result in serious illness and complications for the victim. Whilst the contraction of STIs was not mentioned in any of the experiences analysed, emotional distress can also be experienced by victims who are embarrassed or ashamed about contracting an STI, and concerned about stigma that may be attached to them. Moreover, as Ledray (2005, p. I30) notes, STI testing and treatment are also time-consuming for victims, as they 'must return two or three times for testing' before undergoing any treatment, thus potentially exacerbating both the physical and emotional trauma experienced. As a physical harm recognised in rape cases, and one that is equally as applicable in forced-to-penetrate cases, the potential transmission of STIs highlights a significant similarity consequential upon any form of non-consensual sexual penetration, regardless of the gender of the perpetrator or the victim.

\subsubsection{Emotional and psychological harms}

Within the academic and practitioner literature, it is well recognised that victims of rape often experience more acute emotional and psychological harms than physical trauma. For example, 'fear, stopping previous activities, fear of sex, loss of sexual interest, decrease in sexual pleasure, feeling dishonoured or spoiled, sadness or depression, anger, tension or anxiety, insomnia and fear of being alone' (Byers and O'Sullivan, I998, p. I6I). However, questions are often asked over whether forced-to-penetrate victims experience similar emotional and psychological harms. Indeed, the exclusion of compelled-penetration cases from legal recognition as rape may partly reflect assumptions that 'forced intercourse or oral sex is less traumatic to a man than to a woman just because he was not penetrated' (Muehlenhard, I998, p. 4I). As Muehlenhard (I998, p. 40) argues, it is the act of having one's body penetrated against one's will that marks rape out as a particularly traumatic experience. Moreover, gender stereotyping around masculine sexuality, which posits the notion that 'men should always be sexually available to women, serve(s) to minimise the perceived effects that sexual assault has on men assaulted by women' (Davies and Rogers, 2006, p. 372). That is to say that the stereotype of men always valuing and enjoying sexual interactions, particularly those involving sexually aggressive women, suggests that they do not experience negative emotional or psychological consequences when they are compelled to penetrate a woman.

To some extent, the stereotype that women generally experience (more) emotional and psychological harm than men as a result of non-consensual sexual intercourse is reflected in the (limited) data collected in this area. In Byers and O’Sullivan's (I998, p. I6I) research, which examined the circumstances surrounding sexually coercive experiences, they found that significantly fewer men documented adverse reactions, with ' $49.2 \%$ of the men and $6.3 \%$ of the women' reporting not being at all upset by the incident when it occurred. Similarly, Stock (I998, p. 172) noted that 78 per cent of women reported long-term negative impacts as a result of forced sex, compared to 22 per cent of men. Such results suggest, prima facie, that, whilst there are similarities in the circumstances and the aggressive strategies in male forced-to-penetrate and female rape cases, as documented earlier, this 'does not imply that these experiences have the same meaning and impact on [the] men and women' (Byers and O'Sullivan, I998, p. I62) involved. 
However, when considering the seemingly marked difference in negative emotions experienced by male and female victims, consideration needs to be given to a number of factors. The first, and perhaps most prevalent, of these is the role of pervasive stereotypes surrounding masculinity that enhance men's worth with sexual experience, thus stipulating that men should enjoy all sexual contact with women. This so-called 'lucky boy' syndrome hypothesises those sexual experiences where men do not have to 'work' to get sex as reinforcing their masculinity, and thus as being particularly enjoyable for them. As Struckman-Johnson and Struckman-Johnson (I998, p. I38) argue, 'because young men value and enjoy sex, they are predisposed to view a woman's aggressive advance as a positive sexual opportunity not a violation of will'. The pervasiveness of this 'lucky boy' syndrome is such that some male victims may be unable or unwilling to recognise negative emotions associated with an experience of compelled penetration, or alternatively they may attempt to minimise the seriousness of and harms associated with their experiences. These men may explain what happened to themselves as "I'm a stud, I got laid by"' (LeTrent, 20I3), rather than engaging with the potentially negative emotional complexities of their experience. More broadly, this may also result in male forced-to-penetrate victims failing to recognise their own victimisation.

Consideration also needs to be given to the fact that, whilst it may appear that women generally experience more emotional or psychological harm as a result of non-consensual sex than men, all victims of sexual violence experience different consequences, regardless of their sex or gender. As Muehlenhard (I998, p. 4I) explains, the 'consequences of sexual aggression are affected by the complex meanings that people bring to it'. Indeed, Byers and O'Sullivan (I998, p. I62) noted how, in their own research, they found that influence strategies that were rated as having a negative impact by some respondents were rated as having a neutral or positive impact by other respondents', explicitly noting that it is therefore clear that 'the same behaviour may have a different impact on different people'. They went on to note that 'compared to some women, some men are as distressed or more distressed by their experiences. Some women and some men are not particularly distressed by non-consensual sexual experiences' (Byers and O'Sullivan, I998, p. I64).

Thus, whilst non-consensual sexual experiences may have different impacts on men and women, it is important not to continue to essentialise emotional and psychological harms around nonconsensual sex as only being associated with rape victims who are non-consensually penetrated. Indeed, significant numbers of forced-to-penetrate victims have documented suffering severe emotional and psychological trauma, akin to that recognised in rape victims. For example, Walker (I993, in Fisher and Pina, 2013, p. 60) found that ' $90 \%$ of the male victims in her study could not perform sexually after the assault, and one of the main problems was due to fear of recreating the assault'. Similarly, Orman (1985, in Fisher and Pina, 2013, p. 56) 'reported 24 male victims of female sexual assault and stated that each man found the heterosexual assault exceedingly traumatic .... These men displayed symptoms of post-traumatic stress disorder, and they suffered impaired sexual functioning and aversion to sex'.

In the experiences analysed, nearly all of the male forced-to-penetrate victims reported experiencing emotional and psychological trauma similar to that acknowledged as being experienced by rape victims. This included fear, anxiety and distress, as well as changes in their behaviours towards, and relationships with, women. This is evident in the extracts below:

'I really can't get over it now .... Since that happened my fear of the opposite gender became a little stronger ... I can't think of anyone that would honestly have a clue to what happened to me that one night, but it's all gone now. I6, raped and blinded by fear.' (Jensen, 2014)

'[It] set me on a really dangerous path of random sex with random girls off of AOL chat rooms ... I was not in a healthy place mentally and emotionally. That really messed me up for a long time.' (Jensen, 2014) 
'I've been diagnosed with some amount of PTSD over the incident, and still haven't really trusted anyone other than therapists or my wonderful SO to tell them.' (Jensen, 20I4)

'While I'm able to talk about what happened to me io years later, make no mistake: being raped seriously damaged me and had a profound impact on how I engaged with women years after it happened.' (Jensen, 20I4)

Many victims also reported emotional trauma related to a fear of not being believed, of being stigmatised if they reported what had happened and/or of having their masculinity undermined. The existence of these feelings for forced-to-penetrate victims is both arguably underpinned by, and exacerbated by, the ongoing dominance of the traditional sex script which assigns specific roles to men and women. 'Women are expected to influence men to avoid sex, not to have sex', their sexuality is viewed as 'passive, responsive and receptive' (Muehlenhard, I998, p. 30) and thus they are not recognised as sexual aggressors. In contrast, men have the responsibility of initiating sex, are sexually insatiable and therefore are always expected to consent to, and enjoy, sex. This in turn creates damaging myths and stereotypes around compelled penetration, such as 'women do not sexually aggress against adult men', women are not physically strong enough to compel penetration and 'it is impossible for a woman to have sexual relations with a man who does not desire her' (Struckman-Johnson and Anderson, I998, pp. I I-I2).

As such, in their experiences, some of the men explicitly documented that they did not report their experience to the police or indeed to anyone else for fear of stigmatisation and disbelief:

'Living with the stigma that men should be strong and not be so weak is a struggle as well. So I kept it internally sealed for a long time.' (Jensen, 2014)

'It's one thing to deal with the aftereffect of being raped, but it also was a secondary hit for me oh, you're a guy, how could you be raped by a woman, that makes no sense ... I was afraid to talk to anybody about it because of the stigma I felt I would receive in talking about it.' (Anderson et al., no date)

Others noted how, when they did disclose what had happened to them, they were not taken seriously: 'I felt powerless and ashamed. I told some people but they kind of laughed it off. I think if gender roles were reversed it would've been taken more seriously' (Jensen, 2014).

Finally, one compelled-penetration victim noted how he did not truthfully disclose what had happened, instead framing his experience to others as one that involved consensual sex in order to maintain his masculinity:

'At that point, I decided to own it. Because if I owned it, it wasn't embarrassing and it didn't strip me of my masculinity. I had never heard of this happening to anybody else, and researching it online made my problem seem more real to me, which was frightening. Panic flooded me and all I wanted to do was scrub my soul of everything that was demoralising and demasculinising about the experience. My interpretation became consensual sex, and I proclaimed that sex was awesome, even though I had no clue what it felt like at all. I bragged to my neighbors, who could hear her wailing through paper-thin walls. The more I bragged, the more the agony subsided.' (xojane.com, 2013)

Thus it is clear that, for some men, the dominant societal and gendered constructions around masculinity and the traditional sex script exacerbated their emotional trauma.

Another emotional trauma highlighted in the experiences was the experiencing of uncontrollable sexual arousal, which actually allowed the men to be compelled to penetrate the female perpetrator. Research on male sexual arousal has highlighted that men can experience 
erections 'in various emotional states such as fear and anger ... and [thus it] is not necessarily indicative of pleasure or consent' (Fisher and Pina, 2013, p. 57). Despite this, the myth that 'obtaining an erection during rape denotes enjoyment or event consent' (Fisher and Pina, 2013, p. 57) is still pervasive, often causing men to be asked by others whether they were aroused during their experience (LeTrent, 2013) and with a suggestion that, if they were, then they must have consented. For male forced-to-penetrate victims, this provides an additional layer of emotional trauma, because it is only as a result of their sexual arousal, however it is induced, that they are able to be compelled to penetrate the female perpetrator and thus be victimised. Consequently, in their experiences, men reported feeling 'betrayed' by their bodies:

'I was told once that there is a thing called a "fear boner" I guess that could be the explanation. I was disconnected not in sync with my body, my brain was in over drive mode. So it did its own thing.' (Jensen, 20I4)

'One of the worst things, that I don't see mentioned much, is how you can feel betrayed by your own body. I didn't want that, and yet had an erection anyway, because it's not something you can consciously control.' (Jensen, 2014)

Whilst the issue of body betrayal has been recognised in relation to female rape victims, it has typically been in the context of their bodies experiencing sexual pleasure or orgasms during nonconsensual sexual intercourse. This has also been documented as happening to male forced-topenetrate victims who have reported ejaculation as being particularly traumatic for them. As Rumney and Morgan-Taylor note:

'... acts which involve a man being required to penetrate another do appear capable of creating serious levels of trauma and cannot be easily dismissed from the ambit of rape. Such assaults may be particularly traumatic because they may give rise to a situation in which a man is forced to actively sustain penetration to the point of ejaculation'. (Rumney and Morgan-Taylor, I997, p. 346)

Whilst there may be some differences in the harms experienced by male forced-to-penetrate victims and rape victims, this is hardly unsurprising due to the fact that all victims of sexual violence experience harms personally and thus differently. However, what has become apparent is that there are significant similarities, particularly in relation to the psychological and emotional traumas that victims have reported. Indeed, similarly to female rape victims, male forced-topenetrate victims have documented suffering from anxiety, fear and depression following their non-consensual experiences of sexual intercourse.

\subsection{The 'gender issue'}

As demonstrated through the preceding analysis, there are significant similarities between the experiences of forced-to-penetrate victims and those of rape victims. Both forced-to-penetrate and rape cases involve non-consensual penile-vaginal/anal/oral penetration. Whilst, in forced-topenetrate cases, the victim is the penetrator rather than penetrated, arguments which suggest that this is less of an assault on the bodily autonomy and integrity of the male victim, and thus less harmful, are essentialist and fail to recognise the harms experienced by these men.

Not only are there similarities in the harms, particularly emotional and psychological, for male victims, but significant similarities with what is legally recognised as rape can also be found in the circumstances of the sexual violence and the aggressive strategies used by perpetrators. Therefore, continuing to offer men limited protection under the law because they are penetrator victims, rather than penetrated victims, essentialises the experiences of sexual-violence victims as either 
being harmful, or not, as well as ignoring the experiences of male forced-to-penetrate victims. It is the significant similarities, rather than subtle differences, between compelled penetration and rape victims that should be focused upon to ensure that all victims receive the same level of protection under the law. Indeed, as Scutt notes:

'... a principle of criminal law is, surely, that all persons should be protected equally from harm of like degree .... The case for treating crimes of like heinousness similarly appears to be stronger than that calling for a distinction to be made'. (Scutt, I976, pp. 6I6-6I7)

Despite the arguable strength of arguments to recognise and thus label forced-to-penetrate cases as rape within legal discourse, significant concerns have been raised, particularly by some feminist scholars (see e.g. Mooney, 2006; Novotny, 2002), around such an approach undermining the gendered nature of rape, where men make up the majority of reported perpetrators and women the majority of reported victims. The particular concern raised is typically that the incorporation of compelled penetration within the legal definition of rape would result in a gender-neutral approach being taken, which would mean that the issue of gender would no longer be central to discourse and discussions around rape. More specifically, there is concern that the gender issues faced by women in being the majority of rape victims and in subsequently engaging with legal institutions and with society should not be obscured (Mooney, 2006). In addressing such concerns, Novotny has asked:

'Does male occupation of the victims category represent a disconnect with material reality, as currently mapped, where women are overwhelmingly represented as victims of rape, sexual harassment, and domestic violence? Does de-gendering the victim category distract from this material reality and from efforts to change it?' (Novotny, 2002, p. 748)

In short, my response to such questions is 'no'. It is an unquestionable fact, based upon existing statistics, that the majority of reported rapes are perpetrated by men against women, and it is certainly acknowledged that this is part of a larger societal discourse of women's inequality with men. Indeed, by legally recognising and labelling forced-to-penetrate cases as rape, and thus women as rapists, there is no suggestion that women would become the main perpetrators of rape, nor that men would be more likely to experience sexual violence than women. There is also no suggestion that discussions of gender need to cease, around who either the victims or the perpetrators of rape are. Indeed, quite the opposite. Rather, I would suggest that we need to expand our existing discussions in this area to recognise the possibilities of female perpetrators who victimise men.

Labelling forced-to-penetrate cases as rape should actually have the effect of aiding and encouraging a gendered analysis of rape by providing opportunities for further exploration of the complex dimensions of power which underpin the perpetration of rape. This is particularly so in the case of women who force men to penetrate them, where the dimensions of power cannot immediately be related to patriarchy. Indeed, as Girshick observes in the context of her research on female-tofemale sexual violence (which is also excluded from legal recognition as rape):

'Perhaps our analysis has been wrong all along. Instead of gender privilege being the source of power and control for males, perhaps power and control are equal opportunity variables available to both women and men, previously hidden in the privacy of interpersonal relationships and unspoken sexual violations, and under layers of homophobia and biphobia. If so, women and men must both be targets of prevention and accountability as well as both be activists addressing hierarchical structures of dominance.' (Girshick, 2002, p. 99) 
Recognising and labelling forced-to-penetrate cases as rape would also not detract from the substantial wider issues that exist around ongoing violence against women and girls within a patriarchal culture which permits, and indeed encourages, men to control and subordinate women. Drawing upon previous legal reform where rape was redefined to include male-to-male rape, ${ }^{\mathrm{I2}}$ the discourse has remained gendered in its acknowledgement that rape largely and disproportionately affects women. This is reflected in the majority of scholarship continuing to focus on the typical female victim-male perpetrator paradigm and in the provision of sexualviolence support services for women that greatly outweigh those available for men.

Instead, legally labelling forced-to-penetrate cases as rape would add to the existing debate around sexual violence, and in particular rape, by considering different gendered paradigms around victims and perpetrators. As Rumney argues:

'. . while we must recognise a gendered reality: females are the main victims of sexual violence and males the main perpetrators, one still has to consider how sexual assaults beyond the maleon-female paradigm are to be labelled by the criminal law. The rape of women by men is one of a number of gendered realities in rape'. (Rumney, 2008, p. I44)

So, although it is clear that gender is, and indeed should continue to remain, foregrounded in the context of rape as an offence which disproportionately affects women, it is also clear that the existing gendered definition of rape helps to reinforce the gendered paradigm of women as only being victims and men as only being perpetrators in the context of rape. Although this is largely true in rape cases, as reflected in statistics, this accepted paradigm and thus failure to acknowledge the female rapist has the potential to reinforce damaging gender discourses surrounding the socalled 'ideal offender' and the 'ideal victim'.

Within criminal legal discourse, the 'ideal' criminal offender is, perhaps unsurprisingly, constructed as male. As a rule, crime is something that men do, such that 'crime, men and masculinity have an intimate relationship, so intimate that we often fail to see it, and so intimate that it can seem natural' (Naffine, I997, p. 7). In contrast, the ideal victim is a woman (Christie, I986, p. I8). Indeed, typically, women are viewed as being weak and having to put energy into protecting themselves (Christie, I986, p. I9). This ideal perpetrator-victim construction is problematic for those victims who engage with the criminal justice system and whose experiences do not adhere to this paradigm, either because their experience involved a non-ideal perpetrator(s) or because they themselves were an imperfect victim. Thus, acknowledging the female perpetrator-male victim paradigm through labelling compelled penetration as rape could help to challenge some of these damaging ideal perpetrator-victim gendered constructions, which are also damaging to women.

Perhaps most obviously, legally acknowledging women as perpetrators could help to deconstruct the existing construction of the ideal rapist as always being male. However, by acknowledging women as perpetrators, it also arguably opens up all of the existing discourses surrounding rape for interrogation and deconstruction, and to note both the importance of disrupting, and the dangers of continuing to invoke, constructions around who ideal perpetrators of rape are. For example, it is widely acknowledged within academic and professional discourse that the majority of rape victims know their abuser, yet rape myths continue to exist, situated in the context of a male stranger who attacks a female victim whilst alone late at night (Crown Prosecution Service, no date). Thus, extending the definition of rape to include compelled penetration and thus

I2 Criminal Justice and Public Order Act I994, section I42 substituted Sexual Offences Act I956, section I to provide a broader definition of rape which recognised penile-anal penetration and thus male-to-male rape. This was subsequently reaffirmed and expanded in Sexual Offences Act 2003, section I, where rape was defined as penile penetration of the vagina, anus or mouth. 
recognising women as perpetrators could help to open up more space within existing discourse to add a new dimension to the discussions on 'who rapists are'.

Similarly, labelling compelled penetration as rape arguably has the potential to create a discursive space to interrogate some of the existing constructions surrounding victims of rape. Indeed, as noted above, the stereotypical rape victim is constructed as being female and being attacked whilst walking home alone at night (Crown Prosecution Service, no date). Acknowledging men who have been compelled to penetrate as rape victims could help to develop the existing discussions surrounding the ideal victim. In particular, it is hoped that acknowledging men as the victims of female offenders would help to dispel some of the existing myths regarding men as victims of rape. The consequence of interrogating these gendered constructions surrounding victims and perpetrators could be to encourage individuals to come forward to report their experiences and to feel that they will be believed. This is particularly the case for male forced-topenetrate victims who may feel as if their experiences are viewed as trivial, improbable or impossible.

\section{Concluding thoughts}

In this paper, I have argued that forced-to-penetrate cases should be considered for legal recognition and labelling as rape in England and Wales. Drawing upon the lived experiences of victims, I have argued that there are significant similarities between what is legally recognised as rape and forcedto-penetrate cases, which are currently excluded from such recognition. These similarities are found in relation to not only the involvement of non-consensual penile penetration, but also the aggressive strategies used by both male and female perpetrators, and the physical and emotional harms subsequently experienced by their victims. As such, it is the extent and significance of the similarities between the experiences of many male forced-to-penetrate victims and many female rape victims that underpin my call for a consideration of compelled penetration to be legally recognised as rape.

In making my arguments, I have made clear that the gendered nature of rape should not be undermined. Rather, consideration needs to be given to a wider gendered paradigm of victims and perpetrators within rape discourse to ensure that all victims, regardless of gender, are protected equally from harm of like degree, and that similarly all perpetrators are held culpable. Indeed, as Rumney argues:

$\therefore$.. if we are to be a society that takes sexual violence seriously, then it is important we recognise all victims and perpetrators of rape. It is also of central importance to this process of recognition that sexual violence is correctly labelled by the criminal law'. (Rumney, 2007, p. 5I0)

Whilst, as I noted at the beginning of the paper, consideration of what a reformed legal definition of rape might look like is outside the parameters of this particular paper, consideration of what such a construction might look like in the criminal law is needed. Indeed, future research in this area needs to consider key questions such as: what could a reformed definition of rape look like; what can be learned from the approaches taken by other jurisdictions in relation to incorporating compelledpenetration cases within sexual-offences discourse; and have there been successful prosecutions elsewhere and what have been the consequences of them? In short, a consideration of both the theoretical and the practical implications of legal reform is required. This could be done in consultation 'with criminal justice stakeholders including judges, prosecutors, legal professionals and representatives of victims' groups' (Leahy, 20I4, p. 325).

Finally, further qualitative and quantitative research and data collection in relation to the experiences of male forced-to-penetrate victims within England and Wales are needed. These data would allow a clearer picture to emerge of the prevalence of this sort of sexual violence and the 
experiences of male victims. Further understanding of the experiences of these men is central to ensuring that we do not continue to 'ignore nor trivialise the reality of these men's experiences of sexual coercion [and violence] by women' (Byers and O'Sullivan, I998, p. I62).

\section{References}

AMAR, A.F. and wolbert bURGESs, A. (2009) 'Rape and Its Impact on the Victim' in R.R. Hazelwood and A. Wolbert Burgess (eds) Practical Aspects of Rape Investigation: A Multidisciplinary Approach, 4 th edn. Boca Raton: CRC Press, 25-38.

ANDERSon, N., BRown, E., HeNdrix, S. and svrluga, S. (no date) 'Sexual Assault Survivors Tell Their Stories', The Washington Post. Available at: 〈https://www.washingtonpost.com/graphics/local/ sexual-assault/> (accessed io March 2017).

BLACK, M.C., BASILE, K.C., BREIDing, M.J., SMIth, S.G., WALTERS, M.L., MERRicK, M.T., CHEN, J. and STEVens, M.

R. (20I I) The National Intimate Partner and Sexual Violence Survey (NISVS): 20 Io Summary Report.

National Center for Injury Prevention and Control and Centers for Disease Control and Prevention. Available at:〈http://www.cdc.gov/violenceprevention/pdf/nisvs_report2oIo-a.pdf $\rangle$ (accessed io March 2017).

BOWYER, L. and DALTon, M.E. (I997) 'Female Victims of Rape and Their Genital Injuries', BJOG: An International Journal of Obstetrics \& Gynaecology I04(5): 61 7-620.

BOYLORN, R.M. (2008) 'Lived Experience' in L.M. Given (ed.) The SAGE Encyclopedia of Qualitative

Research Methods: Volume I, Ist edn. London: SAGE Publications, 489-490.

BReIDING, M.J., CHEN, J. and вLACK, M.C. (20I4) Intimate Partner Violence in the United States-20IO.

National Center for Injury Prevention and Control and Centers for Disease Control and

Prevention. Available at: 〈http://www.cdc.gov/violenceprevention/pdf/cdc_nisvs_ipv_report_ 2013_vi7_single_a.pdf $>$ (accessed io March 2017).

Brownmiller, S. (1975) Against Our Will: Men, Women and Rape. New York: Bantam Books.

BYERS, E.S. and o'sullivan, L.F. (I998) 'Similar but Different: Men's and Women's Experiences of Sexual

Coercion' in P.B. Anderson and C. Struckman-Johnson (eds) Sexually Aggressive Women: Current

Perspectives and Controversies, Ist edn. New York: Guildford Press, I44-I68.

Christie, N. (I986) 'The Ideal Victim' in F. Ezzat (ed.) From Crime Policy to Victim Policy: Reorienting the Justice System, Ist edn. Basingstoke: MacMillan, I7-30.

cowan, S. (2010) 'All Change or Business as Usual? Reforming the Law of Rape in Scotland' in

C. McGlynn and V.E. Munro (eds) Rethinking Rape Law: International and Comparative Perspectives, Ist edn. Oxon: Routledge-Cavendish, I54-168.

Crown prosecution Service (no date) Rape and Sexual Offences: Chapter 2i: Societal Myths. Crown

Prosecution Service. Available at: 〈http://www.cps.gov.uk/legal/p_to_r/rape_and_sexual_ offences/societal_myths/\#a2> (accessed Io March 2017).

DAVIES, M. and ROGERs, P. (2006) 'Perceptions of Male Victims in Depicted Sexual Assaults: A Review of the Literature', Aggression and Violent Behavior I I: 367-377.

FISHER, N.L. and PINA, A. (2013) 'An Overview of the Literature on Female-Perpetrated Adult Male Sexual Victimization', Aggression and Violent Behavior I8(I): 54-6I.

GIRSHICK, L.B. (2002) Woman-to-Woman Sexual Violence: Does She Call It Rape? Boston: Northeastern University Press.

HALE., M. (I97I) The History of the Pleas of the Crown. London: Professional Books.

hoffmann, T. (201 2) Voluntary Sex Causes as Many Vaginal Injuries as Rape. ScienceNordic. Available at: $\langle$ http://sciencenordic.com/voluntary-sex-causes-many-vaginal-injuries-rape〉 (accessed Io March 2017). 
HOME OfFICE (2000) Setting the Boundaries: Reforming the Law on Sex Offences. Home Office. Available at: <http://webarchive.nationalarchives.gov.uk/+/http://:/www.homeoffice.gov.uk/documents/ volımain.pdf?view=Binary $>$ (accessed Io March 2017).

JENSEn, L. (2014) I9 Men Share Stories of Being Raped By A Woman (NSFW). Thought Catalog. Available at: 〈http://thoughtcatalog.com/lorenzo-jensen-iii/20I4/08/I9-men-share-stories-of-being-rapedby-a-woman-nsfw/> (accessed io March 20I7).

KRAHÉ, B., SCHEINBERGER-OlWig, R. and BIENECK, S. (2003a) 'Men’s Reports of Nonconsensual Sexual Interactions with Women: Prevalence and Impact', Archives of Sexual Behavior 32(2): I65-175.

KRAHÉ, B., WAIZENHÖFER, E. and MÖLLER, I. (2003b) 'Women’s Sexual Aggression against Men: Prevalence and Predictors', Sex Roles 49(5): 219-232.

LEAHY, S. (2014) "No Means No", but Where's the Force? Addressing the Challenges of Formally Recognising Non-Violent Sexual Coercion as a Serious Criminal Offence', Journal of Criminal Law 78: 309-325.

LEDRAY, L.E. (2005) 'Forensic Medical Evidence: The Contributions of the Sexual Assault Nurse Examiner (SANE)' in J.O. Savino, B.E. Turvey and J.J. Baeza (eds) Rape Investigation Handbook, Ist edn. London: Elsevier Academic Press, I I9-I46.

LETRENT, S. (2013) Against His Will: Female-on-Male Rape. CNN. Available at: <http://edition.cnn.com/ 2013/Io/og/living/chris-brown-female-on-male-rape/> (accessed ro March 2017).

mann, C. and stewart, F. (2000) Internet Communication and Qualitative Research: A Handbook for Researching Online. London: SAGE Publications.

MeZey, G. and KING, M. (I989) 'The Effects of Sexual Assault on Men: A Survey of 22 Victims', Psychological Medicine I9: 205-209.

MINISTRY OF JUSTICE, HOME OFFICE AND THE OFFiCE FOR NATIONAL STATISTICS (2013) An Overview of Sexual Offending in England and Wales: Statistics Bulletin. gov.uk. Available at: 〈https://www.gov.uk/ government/uploads/system/uploads/attachment_data/file/2 I 4970/sexual-offending-overviewjan-20I3.pdf> (accessed io March 2017).

mooney, A. (2006) 'When a Woman Needs to Be Seen, Heard and Written about as a Woman: Rape, Law and an Argument against Gender Neutral Language', International Journal for the Semiotics of Law I9(I): 39-68.

morgan, L., BRitTAin, B. and welch, J. (20I2) 'Multiple Perpetrator Sexual Assault: How Does It Differ From Assault by a Single Perpetrator?', Journal of Interpersonal Violence 27(I2): 24I5-2436.

mueHLenhard, C.L. (I998) ‘The Importance and Danger of Studying Sexually Aggressive Women’ in P.

B. Anderson and C. Struckman-Johnson (eds) Sexually Aggressive Women: Current Perspectives and Controversies, ist edn. New York: Guildford Press, I9-48.

MUEHLENHARD, C.L. and соOK, S.W. (I988) 'Men’s Self-Reports of Unwanted Sexual Activity', Journal of Sex Research 24: 58-72.

Naffine, N. (I997) Feminism and Criminology. Cambridge: Polity Press.

Novotny, P. (2002) 'Rape Victims in the (Gender) Neutral Zone: The Assimilation of Resistance', Seattle Journal for Social Justice I: 743-756.

o'sullivan, L.F., BYers, E.S. and finkelman, L. (I998) 'A Comparison of Male and Female College Students' Experiences of Sexual Coercion', Psychology of Women Quarterly 22: 177-195.

orman., R. (1985) 'Women Raping Men: A Male Secret', unpublished manuscript, in N.L. Fisher and A. Pina (2013) 'An Overview of the Literature on Female-Perpetrated Adult Male Sexual Victimization', Aggression and Violent Behavior I8(I): 54-6I.

RAPE CRISIS (no date) Myths vs Realities. Available at:〈http://rapecrisis.org.uk/mythsvsrealities.php〉 (accessed I3 March 2017).

Rumney, P.N. (2001) 'The Review of Sex Offences and Rape Law Reform: Another False Dawn?', Modern Law Review 64(6): 890-9I0. 
Rumney, P.N. (2007) 'In Defence of Gender Neutrality within Rape', Seattle Journal for Social Justice 6(I): $48 \mathrm{I}-526$.

Rumney, P.N. (2008) 'Gender Neutrality, Rape and Trial Talk', International Journal for the Semiotics of LaW 2I: I39-I55.

RUMney, P.N. and MORGAN-TAYlor, M. (1997) 'Recognizing the Male Victim: Gender Neutrality and the Law of Rape: Part Two', Anglo-American Law Review 26: 330-356.

SARrel, P.M. and masters, W.H. (1982) 'Sexual Molestation of Men by Women', Archives of Sexual Behavior II(2): II 7-I3I.

scuTt, J.A. (I976) 'Reforming the Law of Rape: The Michigan Example', Australian Law Journal 50 : 6I5-624.

Smith, R.E., Pine, C.J. and HAWley, M.E. (I988) 'Social Cognitions about Adult Male Victims of Female Sexual Assault', Journal of Sex Research 24: IOI-I I 2.

SORENSON, S. and SIEGEL, J. (I992) 'Gender, Ethnicity and Sexual Assault: Findings from a Los Angeles

Study', Journal of Social Issues 48: 93-I04.

sтоск, W. (1998) 'Women’s Sexual Coercion of Men: A Feminist Analysis' in P.B. Anderson and

C. Struckman-Johnson (eds) Sexually Aggressive Women: Current Perspectives and Controversies, Ist edn. New York: Guildford Press, I69-184.

Struckman-Johnson, C. (I 988) 'Forced Sex on Dates: It Happens to Men, Too', Journal of Sex Research 24: 234-24I.

Struckman-Johnson, C. and anderson, P.B. (I998) “Men Do and Women Don't”: Difficulties in Researching Sexually Aggressive Women' in P.B. Anderson and C. Struckman-Johnson (eds) Sexually Aggressive Women: Current Perspectives and Controversies, Ist edn. New York: Guildford Press, 9-I8.

struckman-johnson, C. and struckman-johnson, D. (I994) 'Men Pressured and Forced into Sexual Experience', Archives of Sexual Behaviour 23(I): 93-I I 4.

STRUCKMAN-JOHNSON, C. and strucKMAN-JOHNSON, D. (I998) 'The Dynamics and Impact of Sexual Coercion of Men by Women' in P.B. Anderson and C. Struckman-Johnson (eds) Sexually Aggressive Women: Current Perspectives and Controversies, Ist edn. New York: Guildford Press, I 2 I-I 43.

temkin, J. (2002) Rape and the Legal Process, 2nd edn. Oxford: Oxford University Press. TEwKsbury, R. (2007) 'Effects of Sexual Assaults on Men: Physical, Mental and Sexual Consequences', International Journal of Men's Health 6(I): 22-35.

vanderlaan, D.P. and vasey, P.L. (2009) 'Patterns of Sexual Coercion in Heterosexual and NonHeterosexual Men and Women', Archives of Sexual Behavior 38(6): 987-999.

WALKER, J.L. (I993) 'Male Rape: The Hidden Crime', unpublished honours these, University of Wolverhampton, UK, in N.L. Fisher and A. Pina (2013) 'An Overview of the Literature on Female-Perpetrated Adult Male Sexual Victimization', Aggression and Violent Behavior I8(I): 54-6I. weiss, K.G. (2010) 'Male Sexual Victimisation: Examining Men’s Experiences of Rape and Sexual Assault', Men and Masculinities I 2(3): 275-298.

White, C. and mClean, I. (2006) 'Adolescent Complainants of Sexual Assault; Injury Patterns in Virgin and Non-Virgin Groups', Journal of Clinical Forensic Medicine I3(4): I72-I80.

xOJANE.COM (2013) IT HAPPENED TO ME: I Was Raped By a Woman (and Then Dated Her for Two Years). Available at: 〈http://www.xojane.com/it-happened-to-me/it-happened-to-me-i-was-raped-by-awoman-and-then-dated-her-for-two-years (accessed I3 March 2017). 